\title{
Psychological Landscapes and Mines of the Mind: Narrative and Discourse of Red Displacement, White Settlements and Black Laws in the works of Leslie Marmon Silko
}

\author{
Babita Devi \\ Ph.D. Scholar, J.C. Bose University of Science E Technology, YMCA, Faridabad, Haryana, E- \\ mail: babitakpunia@gmail.com, Orcid Id: oooo-0oo2-9699-864X
}

\begin{abstract}
This study explores the possibility of foregrounding narratives and discourses from marginalized communities such as that of Native Indians. It attempts to assess the efficacy of articulating subaltern subjectivities as in Leslie Marmon Silko's works. The article investigates the narrative and informing discourse that propels writing of Native Indian authors who engage with issues like displacement, deviance and behavioural changes in context of the colonial experience. The impact that severed relationships can have on people, the psychological trauma resulting from cultural losses and the intangible changes happening in the recesses of the mind are difficult to quantify, therefore these are conveniently dismissed in mainstream discourses. Yet, the important insights that the subjective perceptions of unquantifiable and intangible losses give is unparalleled and cannot be matched by any scientific claims that may be based on surveys and statistics interpreted within the paradigm of White Man's discourse. Silko's narrative offers a bridge to the other side, the possibility to transcend knowledge and information validated by the Whites and glimpse the world so far relegated and marginalized. At the same time, the present study while valuing the quasi- real or semi-fictional qualities of the narrative, the subjective experiences shared and admitting the significance of deep experiences in which the reader is invited to partake of or witness, also undertakes a lexical analysis of Silko's Ceremony using Voyant Tool to intercept psychological and cultural concerns evoked in the text by studying the frequency of words as they appear in the narrative. The author has often referred to words that have association with land and terrain inhabited by the Natives. This triangulation in research is supposed to be enriching and supportive to the concerns of the authors who many a times use the tools, approach and instruments of West to register their protests emphatically- they use the language of the colonizer, the critical approach of the colonizer and the whole jargon of the colonizer to dismantle the edifice of colonialism. Similarly, this study operates in a way analogous to the text under study by both questioning as well using quantitative research tools to unravel dimensions that may be dear in the given context.
\end{abstract}

Keywords: Natives, whites, land, culture Silko

\section{Subaltern Perspectives shun False Objectivity}

Of course, Silko's approach, like most authors of 'fiction' gives supremacy to subjective experience and makes no claim to objectivity. So, characteristic approach of Native Indians is subjective rather than objective; based on case study rather than quantitative analysis that research

(c) AesthetixMS 2020. This Open Access article is published under a Creative Commons Attribution Non-Commercial 4.o International License (http://creativecommons.org/licenses/by-nc/4.o/), which permits non-commercial re-use, distribution, and reproduction in any medium, provided the original work is properly cited. For citation use the DOI. For commercial re-use, please contact editor@rupkatha.com. 
approaches based on science advocate and hold valid. Yet such quasi-biographical accounts with inputs from real and actual incidents and participatory investigation has many insights to offer. While many psychological investigations and studies may end at just collecting data, the native American authors offer solutions in form of narrative expression by revoking the culture as a living force or a lost way of life. Observation, Experience, Experimentation, Reasoning, Survey, Correlations, and Case Studies all could contribute in some way to resolving societal issues when they turn into research problems. Fictional narratives favour observation that may not be systematic, experiences that may be intuitive or epiphanic, spiritual or beyond reason, reasoning that shows how reason is fallible. correlations that may not have been statistically established but which deep faith grants and case studies, of course, with tools and tests that are non-standard but the author likes to wield. In nutshell, narratives show a reality that science and mainstream discourses do not acknowledge. These narratives offer subaltern perspectives that the laws made by literate, educated Westerners who operate within their own limited frame of right and wrong, just and unjust do not take into account or acknowledge or just misrepresent. The postEnlightenment Western discourse of scientific disciplines dismisses Native Indian beliefs and associations and even culture as superstition. On the other hand, the living Christianity while still upholding creationism claims to represent civilized forms of behaviour while yet practising and believing similar beliefs.

\section{Displacement to Deviation}

A valid question that may be asked in context of the narrative under scanner could be whether a displacement from the native environment or a distancing from Native culture lead to psychological disorientation or behavioural problems. Deviant behaviour in reference to natives may be imputed to usurpation of the land, loss of livelihood and niche spaces articulated and evoked beautifully by Silko in her narratives.

Individual behaviour and changes in the environment yield great insights for sensitive authors and create interpretive context offered by psychological discipline. Interactions amongst these components ecological and human are substantial and when there is dissoci-ation, it may result in behavioural changes. The mainstream discourse omits mentioning or taking note of disturbed relationships or forces that interfere or intervene with the culture.

Psychological traumas and problems came into limelight in the nineteenth century due to the pioneering work of Sigmund Freud and Carl Gustav Jung. In the nascent stage of the field, Freud attributed the psychological problems to psychosexual conflicts. He claimed that every child had to resolve these psychosexual conflicts to grow into a psychologically healthy adult (Carducci, 1998, p 68-70). Freud's disciple Carl Gustav Jung attributed the psychological problems to "Collective unconscious." However, as the discipline grew more and more reasons were added to the causes of psychological illnesses. Pioneering work of Theodore Roszak (1992), for instance, explored the relationship between ecology and human unconscious. Similarly, the development of Native literature has added a dimension of culture to the reasons behind psychosomatic illness. The psychosomatic problems are "endemic among the Natives in the settler countries" (Funk 2, Duran et el 72). It has been observed that "embracing their [Native] culture assists them in achieving sobriety" (Brady 1995, p. 148).

Native literature is one important development in the psychosomatic studies because the Native Writers not only explore the reasons behind the psychological problems of their people; but also suggest that panacea lies in, retrieving culture and resuscitating indigenous traditions. The reasons behind the psychosomatic problems in Native literature boils downs to colonial policies: dispossession of land, de-culturation, taking away of children, destruction of indigenous 
religious beliefs, the list of cultural interference is not exhaustive but whatever be the number or intensity of these disruptions with the normal life of natives, the destructive impact of these forces is evident. It is this destruction as well as forms of protest that have been articulated in Silko's Ceremony.

\section{The Subaltern Can Speak and Write too}

While the literates and educated of the Western society have systematically undermined the ethos of subaltern or colonized sects, voices and writings from the margin have become conspicuous due to assertions of plurality in postmodern world. In cultures that valued traditional lifestyle in consonance with ecology and environment, literacy or education were not given primacy. However, this lack of inclination left these cultures at the mercy of the colonizer's discourse. The Whites could represent the Natives for centuries creating an intellectual and popular environment adverse to an understanding of their values and concerns. Similarly, the legal system put into force by the Whites started with assumptions that excluded the relationship of the Natives with their land. Since property, possession and ownership were outside the culture of the Natives, Whites could conveniently dismiss their claims to the community land and dispossess them.

The last half of twentieth century and the first two decades of current century have seen tremendous growth in Native literature. The societies which were earlier marginalized and invisible to the world especially in the 'settler' countries have been brought into the limelight. Now the people across the world know that there exist Aboriginal people of Australia, Indians of Americas and Maoris of New Zealand. The people who have been exposed to their literature also know about their philosophy and their distinct world view. One thing that is common among all the Native communities is their distinct relationship with land. While the European colonisers treated land as a source of economic riches, the Natives shared a spiritual relationship with land. Dispossession from land is also one of the major sources of psychosomatic illness for the Natives:

[i]n telling the story of an oppressed people there are certain trigger words that are much more than letters strung together in a familiar order; they are symbol loaded with loss and brutality that using the words invokes a shadow of the original suffering. For Jews the word is Holocaust; for Women rape; for blacks, slavery. For Indians it is land. (Martin, 1994, 24)

Leslie Marmon Silko is an important Native American writer whose works explores and tries to re-establish the relationship that was severed during the colonial period. Her writings elaborate the kind of relationship human beings need to save this planet, life and for restoring sanity.

Leslie Marmon Silko herself tells that she was inspired by the land suit that was filed by her people for "six million acres of land" against the state of New Mexico. She writes:

The land claims lawsuit made a great and lasting impression on me. I heard the old folks cry as they talked about the land and how it had been taken from them. To them land was as dear as a child, and as I listened, I felt the loss and the anger too, as if it all had happened only yesterday. (1996, p.19)

The land suit made her realise the "injustice" that "is built into Anglo-American legal system" (1996, p.19). After realising that Anglo-American legal system cannot provide justice to her people, she decided "to seek justice" through the power of the stories" (1996, p.20). 
The most important and popular story she created to seek justice is enshrined in her book Ceremony (1977). The book was hailed as "one of the most realized work of fiction devoted to Indian life" (MacShane 1977, p. 15) and became "one of the most frequently taught contemporary novels in the higher education" (Chakvin 2002, p.4).

The novel tells the story of Tayo, a half-breed Indian who suffers from severe psychological problems. Though half- breed is considered a derogatory term in present discussions, the term carries a history of racial interaction and suggests in the context of Silko's narrative a possibility that is unavailable to both the Whites and deracinated Natives. This possibility is that of reclaiming and resurrecting the native culture, realizing it in a peculiar way when the limitations of White knowledge can be transcended. The White way is as much available to the protagonist as the Native way of life; when he rejects one and embraces another, it is a discursive victory executed through a simple narrative.

The doctors in the hospitals think that Tayo's madness is due to trauma he suffered during the Second World War. However, as the novel progresses, the readers realise that Tayo's madness emanates from the imbalance that has been created on the planet. Capitalists, corporates and organizational gurus too talk of three Ps- People, Planet and Profit when talking of the triple bottomline of 'Sustainability' advocated by John Elkington, but it is a native Indian author who really touches upon the issue, not rendering mere lip service. To restore the sanity; the balance has to be restored.

Tayo could not be initiated into Native culture because he is half-breed and his cousin Rocky are sent to Native school where every attempt is made to deculture them. In the school they are "shamed" and told about the "deplorable ways of the Indian people" (Silko, 1997, p.63) and the beliefs of Indians were termed as "superstition" (96).

When one reads the works of Leslie Marmon Silko, one realises that she blames deculturation as one of the biggest problems. In Ceremony she writes about the boarding school where Rocky becomes de-cultured and starts questioning his people's beliefs. The policy of taking away the children to boarding schools was "practised in the name of assimilation (Pal, 2017, p.196). In Almanac of the Dead, Silko blames these Residential schools for de-culturation:

Sterling knew that sending the children away to boarding school was the main problem. He and the other children had to learn what they could about the Kachinas and the ways to pray or greet the deer, other animals, and plants during summer vacations, which were too short. (1991, p.87-88)

The above lines make clear that during their stay in the boarding schools, the Indians were taught that the institutions erected by the Whites and the knowledge-systems, paradigms of understanding that Whites have globalized are contemptuous of local cultures: Indians' ways are mocked at and their traditions are relegated as mere superstitions. The children were allowed to come home only during the summer vacations. At home they could get trained in their own culture, but the summer vacations were too short to learn all the aspects of their culture. This policy is also at the root of alcohol and drug abuse:

Drug and alcohol abuse and ill-health too, are said by many indigenous people to have arisen from, or been exacerbated by, deprivation and erosion of their cultural integrity (acculturation) as result of colonization. (Brady, 1995, p.1489)

In Ceremony, the readers find that most of the young Indians are alcoholics; the only exception is Tayo's uncle Josiah. Silko seems to suggest that Josiah has retained his sanity only 
because he had not attended the White educational institutions. He tells Tayo: "Well, I didn't go to school much" (1977, p.93). Thus, the Marxian idea of superstructures that uphold White capitalism, the institutions adding to the ideological state apparatus, the whole machinery of subjugation is perceptibly working and taking toll on native lives. The colonial education system de-cultured the Indians, but at the same time heightened their sense of loss. That is why the whole generation of the Indians is distressed and their only refuge is alcohol. Noted Australian Aboriginal writer Alexis Wright points out that alcohol is drunk by the Natives to "dull the pain. A pain which was like sledgehammers with blunt knives attached hammering inside his head" (Wright 1997, p.11). Alcohol provides temporary relief to the people. The elders of the community know that they are witnessing the destruction of a whole generation that is why the Medicine Man tells Tayo to complete the ceremony. He tells Tayo: "It is important to all of us. Not only for your sake, but for this fragile World" (1977, p.33). The ceremony completed by Tayo will restore the balance of the "fragile World" (1977, p.33). Thus, if Tayo completes the ceremony, the world will be saved and the mental health of the Indians will be restored and their "spoiled, scarred psyches" (Maracle, 2000, p.7). Maracle further elaborates about ceremony:

Ceremony, a necessary act to obtain or regain balance with the earth, replenishes her love for humankind. The purpose of Ceremony is to integrate: to unite one with all of humankind as well as the realm of ancestors, to blend one with all of creation. (2000, p.7)

There are many studies that have indicated that there is connection between "reduction of stress" and contact with the land (especially traditional land) (Kingsley, Mardie Townsend et. al. 2009, p.62)

In fact, one of the important aspects of colonial regime was ethnocentrism. All cultures were evaluated from the perspective of Europeans or Americans, that is, the West. Blinded by their brand of ethnocentrism, the colonizers were very 'rational' while probing the beliefs of the colonized while ignored their own fallibilities and civilizational failings. This attitude has been exposed by Chinua Achebe, an Igbo Nigerian author whose observations nevertheless hold true for the numerous cultural sects that were subordinated by the Whites (Pal, 2018, p.152). The colonial experience of Black Americans and Red Indians may be disparate, as were the conditions of their existence but these communities can empathize with each other better because of parallel or analogous experiences and the White approach to subjugated races. Many over-arching themes are shared when colonial experience is defined or described.

The Indians have also exposed this hypocrisy of the Whites.

Indian people feel that it is very poor manners to refer to the Buffalo Calf Woman's appearance as a myth or superstition. Indians do not scoff at the story of the Israelites fleeing Egypt when the Red Sea was parted by the Great Spirit in order for the Jewish people to escape the Pharaoh's pursuing army. We have been told over and over by Christian missionaries that a man, born of a Virgin, died, rose again three days after his death, pushed a big stone back from his tomb, and then ascended to the spirit World. (Eagle Man, 1990, p.6)

The above lines make clear that the spiritual stories cannot be questioned and there are no rational explanations for such stories; but at the same time these stories are part of unconscious of the people. If these stories; or on the large the culture of the people is dismantled and questioned, then it creates enormous psychological problems for the adherents. In case of the Native societies, the fountain spring of their culture is land. If they are taken away from land then the psychosomatic problems are sure to follow. In case of Americas, Natives were removed from 
their lands through "the removal act that was enacted in 1830 by President Andrew Jackson" (Pal \& Divyajyoti Singh 37).

\section{Recovering the Sacred Hoop: Symbiotic Relationship of Men and Earth}

In Ceremony, Silko clearly reveals that Tayo's problems are not due to "battle fatigue" (1977, p.7, 28) as thought by White doctors; rather it due to his disconnection with the outer world. He kills flies because he is taught that they "are bad and carry sickness" (1977, p.93) in the colonial school. This is in direct contrast to the Native world view which treats every living as sacred. Jan Hatke points out:

Native American Indians learned how to live with the earth on a deeply spiritual plane. Their intuitive sense of intimate connection with all of existence from Brother Bear to Sister Stone to Father Sky to Mother Earth. (1990, p xiv)

Paula Gunn Allen calls this symbiotic relationship "the sacred hoop" (1986, p.1) in this sacred hoop "everything has its place in it" (1986 p.1). This symbiotic relationship is visible in Ceremony also. Silko tells the readers that people sprinkled corn on the nose and fed the deer's spirit" (Silko 1977, p.47) because they believe that "the deer gave itself to them because it loved them" (Silko, 1977, p.48). This ritual was followed by all the Indians even "the Catholics who went to mass every Sunday" (Silko, 1977, p.48). Silko tells about the hunt in other writings also:

The Antelope merely consents to return home with the hunter. All phases of the hunt are conducted with love: the love of the hunter and the love of the antelope who agree to give up their meat and blood so that human beings will not starve. (Silko 1996, p.26)

The ceremony in the novel Ceremony consists of restoring this harmony between man and nature. Tayo after getting initiated into the ceremony start realising the connections between the earth and the Indians:

It was soothing to rub the dust over his hands; he rubbed it carefully across his light brown skin, the stark White gypsum dust making a spotted pattern, and then he know why it was done by the dances; it connected them to the earth. (Silko, 1977, p.96)

In the preface to the novel, Silko herself writes that "Mt. Taylor, or T'Sepina is a sacred mountain central to much of the novel" (1977, p.xviii). The importance of the Mount Taylor is obvious from the fact that it is referred to as "sacred mountain" $(1977$, p.92) in the novel.

\section{All that 'paperwork', Its 'Deeds' and Mis-'Deeds'}

In fact, the Natives across the world believe the land cannot be owned by anyone. An Australian Aborigine says: "When the land is taken from us or destroyed, we feel hurt because we belong to the land and we are part of it" (Cited in Swain 1991, p.15). In Ceremony, Silko also reiterates the same thing. Medicine man Betonie tells Tayo:

They only fool themselves when they think it [Mount Taylor] is theirs. The deeds and papers don't mean anything. It is the people who belong to the mountain. (1977, p.118)

The importance of land is obvious from the attitude of the Natives towards the land. While for the Whites the land is only an economic commodity; for the Natives it is an ancestor; a living thing: "People talk about Country in the same way they would talk about a person; they speak to country, visit country, and long for country (Bird, 1996, p.6). And it has been observed that "Australian Aborigines, Navajos and any number of Indigenous peoples have reported this sense of mournful disorientation after being displaced from land" (qtd. in Smith, Daniel B.). The 
unique relationship of the Natives with the land was severed when they were forced to dislocate from their lands to other places.

The basic assumption which gave the conceited Whites to impose and enforce law and legal frame in their land of settlement excluded the most fundamental question- did Whites have any claim to the land they had happened to land upon?

The scales were already tilted in the favour of the White. After the basic 'truth' of White ownership was taken for 'granted' the law could take its course and operate. Naturally, the suits could arise only between Whites as only these had the 'ownership' ; the Indians had had no paper, no deeds and no claims. Bruce E. Johansen says that this "rationale stemmed from the European Doctrine of Discovery by which an old-world sovereign could assume ownership of New World by laying eyes upon it, mumbling a few ritual words about God and country, and compensating the Natives with presents and a piece of paper laced with words they usually couldn't read" (2006, p.vii).

\section{Cultural and Psychological Concerns Revealed through Semiotic and Lexical Analysis of Silko's Ceremony}

Silko knows that the land was taken away from her ancestors by deceit that is why she uses the phrase "stolen land" (1977, p.177) repeatedly in the novel. Nowadays a lot many online tools allow the readers to analyse text. When the novel is analysed on Voyant tools ${ }^{1}$, it shows that word "mountain" appears in the text for 94 times and word land appear for 52 times. The repetition of both the words shows that these are extremely important words for the analysis of the text.

The 'stolen land is a source of great psychological stress to the Natives. The "relationship between the land and Natives is that of a mother and Children:

Come out. Come home again.

Your mother, the earth is crying for you.

Come home, children, come home.

(Silko 1977, p.163)

If a child is removed from his mother then the child develops severe psychological problems. According to John Bowlby if a small child has to become a healthy adult, "the infant and young child should experience a warm, intimate and continuous relationship with his mother (or permanent mother substitute) in which both find satisfaction and enjoyment" (Bowlby, 1951, p.13). In the case of the Indians, the psychological problems were inevitable because their mother was forcibly removed from them. Once the mother was removed from them their psyche got debilitated and disturbed and alcoholism became their only refuge.

\section{Land, Mines and Mind: Displacement is not just a physical but a psychological experience}

Mining is the most destructive activity designed by the human beings. Australian Aboriginal writer Mudrooroo has compared mining to rape:

They did approach mining operations as if it was a sexual act, hard thrust without a care for the women beneath without a care for the Universe, the land beneath, We'll fix it up when we are done with her, much like the battered Vilife syndrome. (Mudrooroo, 1993, 570)

According to Mudrooroo, for a Native to see the earth getting mined in front of one's eyes is like, seeing one's mother getting raped in front of one's eyes. In case of Silko's people it is even worse because the uranium mine is located in Mount Taylor which is considered sacred by the Laguna people. Per Seyersted Writes: 
Today, north western New Mexico is the largest uranium producing region in the world; it has the largest open pit uranium mine in existence, the Jackpile Mine, near Paguate on Laguna Land, and the deepest uranium shaft, sunk into Mt. Taylor, a mountain northwest of Laguna which is sacred to the Pueblo and Navajo People. (12)

It is a source of great psychological stress to the people to see their land getting violated; but they are unable to do anything to save their land/mother. This kind of situation is called "learned helplessness" (Wesley-Esquimaux 66). This sort of behaviour is exhibited by when "an individual (or a group) perceives that his or her behaviour cannot control events and that no action on his or past will control outcomes in future" and ultimately through "learned helplessness trauma enters psychological makeup of a person” (Wesley-Esquimaux, 2004, p.66).

Mining is quite stressful for the communities. Glenn Albrecht carried out research in Hunter Valley Australia where the people of the place were under stress because of the mining activities going on in the surrounding. Albrecht found and wrote about the problems of the residents:

Their sense of place, their identity, physical and mental health and general well-being were all challenged by unwelcome change. Moreover, they felt powerless to influence the outcome of the change process. From the transcript material generated from the interview the following responses clearly resonate with the dominant components of solastalgia the loss of ecosystem health and corresponding sense of place, threats to personal health and well-being and a sense of injustice and/or powerlessness. (Albrecht 2007, p. S96)

These responses were recorded from largely white residents of community. They were distressed only because their aesthetic sense was violated. They had to watch the earth being dug and the beautiful landscape of their surrounding getting altered accompanied by the continuous noise. The people felt distressed because the landscape they were used to was getting violated. The problems of the Natives are much deeper. Activities like mining disturb their way of life. Due to mining they are suddenly left nowhere. The impact of mining includes:

- A loss of ability to hunt, fish and gather,

- a loss of freedom of movement

- locals being forced to resettle or relocate

- a fundamental disrespect for traditions

(Hilson, 2001, p.66)

This kind of alteration in life style can lead to much severe consequences.

The case of Natives in ceremony is even more complicated because here they are not just distressed by mining, the impact goes beyond the summary interpretation and definition in terms of 'distress'. The Laguna lands are being mined for uranium which is used for destruction of the planet. This kind of destruction is against the philosophy of the Native Indians. The destruction caused by the atomic bombs in Hiroshima and Nagasaki shook the world; but the Laguna people were more distressed because the uranium used by the destroyers was extracted from their land.

\section{The Primal Assault}

If the analogical relationship of man and land is that of mother and child in Red Indians' understandingthen dissociation from land and the way this land is used by the Whites may have deep repercussions. Natives consider Land as their mother and mother always protects her children and nourishes them. Under any circumstances, mother does not think I'll of her children; but the destroyers have started using fruits of her womb to wreak havoc on the world. This realisation further complicates the psychological problems of the Natives: 
The gray stone was streaked with powdery yellow Uranium, bright and alive as pollen; Viens of sooty black formed lines with the yellow, making the mountains ranges and rivers across the stone. But they had taken these beautiful rocks from deep within the earth and they had laid them in a monstrous design, realizing destruction on a scale only they could have dreamed. (Silko1977, p.229)

Here in Ceremony, the readers see that two different ideologies are engaged in a struggle. One side wants to destroy, while the other side marginalized one represented by Indians want to preserve. Silko exposes diabolic and destructive materialism and "rugged Individualism" (Pal, 2018, p.151) of the whites. It is due to the greed for individual riches that the whites espoused a life/style and developed an economic system which resulted in higher concentration of $\mathrm{CO}_{2}$ gas than "any point in the last eight hundred thousand years" (Kolbert, 2014, p.113). Now this destruction of the ecology is gnawing at the psyche of the human beings" (Pal, 2019a, p.430).

\section{White Lies}

In fact, dislocation has been done in Americas to satisfy the greed of the Whites. Most of the Native writers have addressed the issue of dislocation of the Natives. Louise Erdrich, for instance, in her novel The Birchbark House shows "how dislocation affected the cultures of Ojibwe" (Pal, 2019, p.2). These kinds of writings are important because they expose the realities of dislocation and dispossession of the Indians by Whites. The narratives and policy documents written by the White government officials portrayed the policies as "philanthropic and benevolent" (Washburn, 1968, p.49). Moreover, so many studies have indicated that "People have heart's ease when they're on their own country. If you force them off that country, if you take them away from their land, they feel the loss of heart's ease as a kind of vertigo, a disintegration of their whole life (qtd. in Smith, Daniel B.). Anybody who comes across novel like Ceremony realizes this truth.

One of the major stereotypes of the Indians is that of an alcoholic. Silko has also been criticized "for her portrayal of alcoholic Indians in the novel" (Chakvin, 2002, p.5). Silko shows alcoholic Indians in the novel, but she also exposes the reason behind this alcoholism. She shows the colonial policies pursued by the Whites are greatest reason behind alcoholism of the Indians. Almost every Indian in the novel is bitter about 'stolen land' and this bitterness leads to alcoholism. Silko and other Indian wordsmiths have an agenda when they take pen in their hand. Paula Gunn Allen points out the agenda: "We are here to testify that our traditions are valuable to us, and that we continue to resist obliteration either of our culture or our personhood (1989, p.2).

\section{Relegation to Foreground; New Historicism has its blessings}

In her career, Silko has earned the reputation of an advocate for the rights of her people. She has developed an uncanny ability of foregrounding her people's real history and traditions. Kenneth Rosen writes about her. In Leslie Silko's hands the theme becomes a potent symbol of the age-old conflict between the invading whites and the Indians they relentlessly pursue (Introduction, 1974, p.xi). In her epic novel Almanac of the Dead she exposes all the aspects of colonial policies that are at the root of the psychosomatic problems of the Natives.

The best way to save the Indians from these psychosomatic problems is to reconnect them with their "Cultural and spiritual roots" (Brady, 1995, p.1489). This is what Indian writers like Silko are trying to do. They are trying to remind Indians about their roots and their culture through their writings. The cultural amnesia that was induced by colonial policies is being shattered by these writings. The writings of the Natives are not only helping in preserving their culture, but are also inducing/invoking a pride among the Natives for their culture. 
Silko's stand is clear. She tells the Indians in no uncertain words that they are the real inhabitants of the continent of America. The Whites have tried to obliterate Indian culture and in "cultural genocide" (Tinker 1993, p.5). Since their arrival on the American continents, the Whites have waged a direct and indirect war against the Indians. Silko also reiterates the same stand:

War had been declared the first day the Spaniards set foot on Native American soil, and the same war had been going on ever since: the war was for the continents called America. (133)

The call for the Indians is clear to resuscitate their culture and identity because the war has moved to a new plane. The identity of Indians is as certain by the government. This identity is generally ascertained on the basis of blood quantum. Now if the intermarriages "proceed as it had been for centuries, and eventually Indians will be defined out of existence" (Schmidt, 2011, p.6)

Silko knows that this war can be fought only and only if the Indians regain their sanity. If they will remain drowned in alcohol, then they have no chance of winning this war. They will be soon defined out of existence and the continents of Americas will automatically be owned by the Whites.

\section{Calling a Spade a Spade}

Silko as a conscious writer understands the problems that emanate from colonial policies. Her writings make clear that Indians of United States of America has not yet entered postcolonial era. They are still oppressed by the White governments; where the government decides what is good for the Indians and what is not. They are not offered employment opportunities and their land has been 'stolen' from them so they have to indulge in criminal activities like smuggling to make their ends meet. The population of Indians in jails is much more when compared to the Whites (King, 1993, p.85). Silko writes about the reason:

Zeta wondered if the priests who told the people smuggling or stealing had also told them how they were to feed themselves now that all the fertile land along the rivers had been stolen by White men. (1991, p.133)

Silko makes clear that the criminal activities like smuggling are a direct result of dispossession by the Whites.

Thus, writings of Leslie Marmon Silko are a desperate attempt to restore the sanity of her people. She makes it clear that if her people have to survive as a community then their cultural practices have to be restored and retrieved. The culture of the Indians emanates from land. So, land rights are important for their mental and physical health.

\section{Closure not Conclusion: Striking at the Roots}

The case does not rest; the problem has not ended because evoked and one desirable solution shown to manifest in Silko's narrative. Prima facie, the author has embarked on an impossible task- turning the wheel back in time. If she strikes at the roots - well, the settler's do not even have their roots in the land yet they do not stay in America as refugees or underprivileged people who lose home. They are the privileged lot who have driven the real inhabitants out and have usurped and inherited what had 'belonged' to the other. This vocabulary of what belongs and who belongs itself exposes the inequalities manifest in the Western language and discourse. The natives belong to land, land does not belong to them. This very founding principle makes the Indians vulnerable and exposes them to the Western incursion. Yet, Silko stays firm in her convictions. 
As a writer, Silko understands the politics of the government. She questions the legitimacy of the government itself:

There was not, and there never have been, a legal government by Europeans anywhere in the Americas, Not by any definitions, not even by the Europeans own definitions and laws. Because no legal government could be established on stolen land. Because stolen land never had clear title. (1991, p.133)

Silko's stand is clear that because the government is not legitimate so the government cannot decide who is Indian and who is not. The Indians only need to realise this and come out of alcoholism to wage a fight because now it is the question of survival.

\section{References}

Albrecht, Glenn, Gina Maree Sartore, Linda Coonoret el. 2007.Solastalgia: The Distress caused by Environmental Change. Australian Psychiatry 15.S1, 595-598 web http://healthhearth.blogspot.in.

Allen, Paula Gunn. 1986. The Sacred Hoop: Recovering the Feminine in American Indians Traditions. Boston: Beacon Press.

Allen, Paula Gunn. 1989. Spider Woman's Grand daughter:Traditional Tales and Contemporary Writing by Native American Women. New York: Random House.

Bird, Deborah. 1996. Nourishing Terrains. Canberra: Australian Heritage Commission. Web http://www.environment.gov.au

Bowlby, John. 1951. Maternal Care and Mental health. World Health Organization Monograph. (Serial No. 2).

Brady, Maggi. 1995. Culture in Treatment, Culture as Treatment: A Critical appraisal of Development in Addiction Program for Indigenous North Americans and Australians.Social Science Medicine. 41.11,1487-1498

Carducci, Bernardo J. 1998.The Psychology of Personality. Pacific Grove: Brooks/Cole Publishing Company.

Duran, Bonnie, Margaret Sanders, Betty Skipper et al. 2004. Prevalence and Correlated of Mental Disorders Among Native American Women in Primary Care. Public Health 94.1 (Jan). www.ncbi.nlm.nih.gov/pmc/articles/PMC1449829

Eagle Man, ED MC Gaa, 1990. Mother Earth Spirituality: Native American Paths to Healing Ourselves and Our World. San Francisco: Harper Collins.

Hatke, Jan. 199o. Introduction.In Ed McGaa, Eagle Man. Mother Earth Spirituality: Native American Paths to Healing Ourselves and Our World. San Francisco: Harper Collins.

Hilson, Gavin. 2002. An overview of Land Use Conflicts in Mining Communities. Land use Policy, 19, 65-73.

Johansen, Bruce E. 2006. Series Forward.In Robert J. Miller. Native America, Discovered and Conquered: Thomas Jefferson, LewisE Clark and Manifest Destiny Connecticut Praeger.

King, Thomas. 1993. Green Grass Running Water. Toronto Harper Collins.

Kingsley, Jonathan Yotti, Mardie Townsend, Rebecca Phillips et el. 2009. "If the land is Healthy it makes the people healthy": The Relationship between Caring for Country and Health for the Yorta Nation, Boonwurrung and Bangrang Tribes. Health E Place 15: 291-299

Kolbert, Elizabeth. 2014. The Sixth Extinctions: An unusual History. New Delhi, Bloomsberry. Maracle, Lee and Sandra Laronde. 200o.My Home as I Remember. Toronto: Natural 
Heritage/Natural History Inc.

Martin, Sandra. 1994. This Land is whose Land? [Reiew of novelGreen Grass Running Water, by Thomas King]. Q.uiell Quire (May).

Mudrooroo. 1993. Mining the Earth with minding the Earth. World Literature Today 67.3 (Summer): 569-576.

Pal, Virender.2017. Unlearning at White Settlers School; Erasure of Identity and Shepherding the Indian into Christian Fold: A Study of Shirley Sterling's My Name is SeepeetzaRupkatha, Journal on Interdisciplinary Studies in Humanities 9.1, 195-205.

Pal, Virender. 2018. The Prodigal Sons of Africa Proselytized to Christianity: Cultural Renegades and Apostates in Achebe's Novels. Rupkatha Journal on Interdisciplinary Studies in Humanities, 10.2; 148-157.

Pal, Virender \&Divyajyoti Singh. 2019. "Re-storying" to Reverse the Game of Silence. Louise Erdrich's Narrative Rescue from Reductive Western Discourses. The IUP Journal of English Studies 14.3 (Sept)::30-40.

Pal, Virender. 2019a. Ecological Degradation, Disintegration Psyches and complicated Narratives: The Red and the White of Settler Colonies. International Journal of Psychosocial Rehabilitation. 24.04. p.430-440.

Pal, Virender. 2019b. Disease, Dislocation and Deprivation in Louise Erdrich'sTheBirchbark House: Exposing the White Lies of the Civilizing Discourse. Rupkatha Journal on Interdisciplinary Studies in Humanities 11.2(July-Sept) : 1-19.

Rosen, Kenneth. 1974. Introduction. The Man to send Rain Clouds. New York: Penguin Books.

Silko, Leslie Marmon. 1977. Ceremony. New York: Penguin.

Silko, Leslie Marmon. 1991. Almanac of the Dead. New York: Penguin.

Silko, Leslie Marmon. 1997. Yellow Woman and a Beauty of the Spirit. New York: Simon \& Schuster.

Silko, Leslie Marmon. 2010. The Turquoise Ledge: A Memoir. New York: Penguin.

Seyersted, Per. 1980. Leslie Marmon Silko. Idaho: Boise State University.

Smith, Daniel B. 2010. Is there an Ecological Unconscious? Web http://www.nytimes.com 12 July 2012.

Swain, Tony. 1991. The Mother Earth Conspiracy. Numen 38.1 (Jun): 3-26

Tinker, George E. 1993. Missionary conquest: The Gospel and Native American Cultural Genocide. Minneapolis: Fortress Press.

Schmidt, Ryan W. 2011. American Indian Identity and Blood Quantum in the $21^{\text {st }}$ Century: A Critical Review. Journal of Anthropology, 1-9.

Washburn, Wilcomb E. 1968. Indian Removal Policy: Administrative, Historical and Moral Criteria for Judging its Success or Failure. Ethnohistory 12.3, 274-278.

Wesley-Esquimaux, Cynthia\&MagdalinaSmolewski. 2004.Historic Trauma and Aboriginal Health. Ottawa: Aboriginal Healing Foundation. Web http://www.ahf.ca

Wright, Alexis. 1997. Grog War. Broome Western Australia Magabala Books. 